Vol. 39(2), pp. 165-176, Dec. 2020

ISSN 1821-536X (print)

ISSN 2619-8789 (electronic)
Tanzania Journal of Engineering and Technology Copyright (c) 2020 College of Engineering and Technology, University of Dar es Salaam

Full Length Research Paper

\title{
Effects of Calcination Temperature of Naturally Occurring Absorbents on Drinking Water Defluoridation
}

\author{
Brenda A. Mndolwa ${ }^{1}$ and Felix W. Mtalo ${ }^{2}$ \\ ${ }^{1}$ College of Earth Sciences and Engineering, University of Dodoma, Tanzania \\ ${ }^{2}$ Department of Water Resources Engineering, University of Dar es Salaam, Tanzania \\ Corresponding author: brenda.mndolwa@gmail.com
}

\begin{abstract}
Currently, in Tanzania, fluoride removal from drinking water is treated mostly using the bone char method. The method has poor acceptability in some religious communities and also causes water quality deterioration in taste and odour if the bones are not properly prepared. The use of local natural adsorbents as an alternative is feasible with limitations of high levels of other impurities in treated water. Locally available gypsum, magnesite and bauxite were converted to adsorbents through calcination. The study was conducted to determine the removal efficiency, best calcination temperature and composite ratio of the three adsorbents for the removal of fluoride from natural drinking water with fluoride concentration as high as $16.7 \mathrm{mg} / \mathrm{L}$. The adsorbent materials were calcined at different temperatures ranging between $350^{\circ} \mathrm{C}$ and $600^{\circ} \mathrm{C}$. Batch experiments were performed and samples were collected at different contact time intervals of 2 minutes to 60 minutes, and residual fluoride was determined. Bauxite had the highest fluoride removal efficiency compared to gypsum and magnesite. The best calcination temperatures were $350^{\circ} \mathrm{C}, 400^{\circ} \mathrm{C}, 600^{\circ} \mathrm{C}$ for gypsum, bauxite and magnesite, respectively. The best calcination temperatures were used to prepare composites at different ratios of 1:2:3, 2:3:1 and 3:2:1, bauxite: gypsum: magnesite respectively. All the ratios gave low sulphate and iron as impurities within the recommended standards. The composites lowered fluoride concentration level to $1.53 \mathrm{mg} / \mathrm{L}, 2.07$ $\mathrm{mg} / \mathrm{L}, 2.60 \mathrm{mg} / \mathrm{L}$ for 1:2:3, 2:3:1, 3:2:1 ratios, respectively. In conclusion the study reveals that, it is possible for composites made of adsorbent calcinated at different optimum temperatures to give good results in fluoride removal from drinking water, as well as standard $\mathrm{pH}$, iron and sulphate values in treated water.
\end{abstract}

Keywords: Fluoride, Bauxite, gypsum, magnesite, composite ratio, adsorbent.

\section{INTRODUCTION}

Fluoride is the pollutant that is persistent and cannot be degraded and has the ability to accumulate in the soil, plants, animals and also in human beings body (Tomar and Kumar, 2013). In different parts of the world, contamination of drinking water with excess fluoride content has been described as one of the public health problem (Lavecchia et al., 2012). Water with excess fluoride and other chemical and biological contents above the recommended drinking standards is not suitable for domestic use (Rao, 2003). Moderate amount of $1 \mathrm{mg} / \mathrm{L}$ of fluoride is 
of importance in human dental health by preventing dental caries, but too low fluoride concentration is serious especially in children health growth in development of their tooth enamel since it is considered to be less developed at the childhood stage (Owusu-Agyeman et al., 2018). Fluoride plays a major role in bone and dental mineralization, but when it is in excess it can cause severe and serious health effects such as dental fluorosis, skeletal fluorosis and long term damage of thyroid, liver, kidney and brain (Lavecchia et al., 2012).

Fluoride in water is unable to bind with cations such as aluminium and iron because of their low reactivity in natural water, hence fluoride occurs as a free ion. Fluoride can occur naturally or due to human activities. Naturally, its occurrence is mainly related to geogenic processes, which govern its concentration in groundwater. It is affected through the contact with the sedimentary carbonates (Sivasankar et al., 2016). Moreover, the aquifer characteristics can also contribute to presence of fluoride contamination into groundwater after a prolonged contact with aquifer fluoride rich minerals. In aquifers of volcanic formation, mineral dissolution is inhibited due to the low temperature, high altitude and high transmissivity features of the aquifer hence resulting in low fluoride concentration. For the case of sedimentary formation aquifers they are characterised by low altitude and high temperature which facilitates dissolution of minerals and allow precipitation of $\mathrm{CaF}_{2}$ hence leading to high fluoride concentration in groundwater (Shen et al., 2016)

Volcanic activities are one of the natural sources of fluoride contribution to the environment, whereby varieties of gases containing $\mathrm{HF}, \mathrm{NH}_{4} \mathrm{~F}, \mathrm{SiF}_{4},\left(\mathrm{NH}_{4}\right)_{2} \mathrm{SiF}_{6}$, $\mathrm{NaSiF}_{6}, \mathrm{~K}_{2} \mathrm{SiF}_{6}$ and $\mathrm{KBF}_{4}$ and few other minor constituents such as sulphate can be emitted when volcanic activities takes place (Borgnino et al., 2013). Also, a significant amount of soluble compounds including fluoride are being released into water when the fresh-erupted tephra gets in contact with water resulting to the contribution of fluoride concentration in water (Ayris and Delmelle, 2012).

Fluoride pollutants can be present in air, dental products, food and beverages, soil as well as in water (Fawell et al., 2006). As a result of human activities, in the process of manufacturing different products, the industries can release fluorine to the environment either in form of gas such as $\mathrm{HF}, \mathrm{SiF}_{4}, \mathrm{~F}_{2}$, and $\mathrm{H}_{2} \mathrm{SiF}_{4}$ or in a form of particulate matters that is $\mathrm{CaF}_{2}, \mathrm{NaF}$, and $\mathrm{Na}_{2} \mathrm{SiF}_{6}$ (Ozsvath, 2015).

The problems of excessive fluoride amounts in drinking water are highly endemic and hence they have encouraged and motivated more researchers to explore different methods and materials that can be used to solve the problem (Rao, 2003). Over years, as a result of different research conducted in different places worldwide, there have been development of techniques for removal of fluoride (Al-Hawamdeh et al., 2013).

Fluoride removal techniques include Nalgonda technique, reverse osmosis and nano-filtration, electro-coagulation technique and precipitation. Similarly using different adsorption materials such as activated alumina, bone char, clay and aluminium have been proven to be effective. However, most of them appeared to be neither sustainable nor effective in remote rural regions of developing countries mainly due to their high cost and dependence on skilled personnel for maintenance (Cherukumilli et al., 2017).

These techniques face setbacks whereas some are not cost effective and others are less expensive but less effective with low quality of the treated water as well as poor sorption capacity (Al-Hawamdeh et al., 2013; Thole and Mtalo, 2012). Each 
technique has its benefits and shortcomings that limit its use. For instance, membrane separation process which includes reverse osmosis and nanofiltration, are very efficient but it suffers from high energy consumption and membrane fouling, hence making it expensive, whereas chemical precipitation tend to produce large amount of sludge (Cherukumilli et al., 2017). Among the setbacks of Nalgonda method is the formation of sludge, high chemical dosage, requires a technical personnel to operate and it is not suitable for water with high fluoride content greater than $10 \mathrm{mg} / \mathrm{L}$, (Wambu et al., 2014). The use of bone char, interferes with some taboos and religious beliefs of some societies hence it is not accepted globally and when not properly prepared produces low water quality with taste and odour of rotten meat to drinking water. Bauxite and clay increases water turbidity, colour as well as some of the residual ions (Thole and Mtalo, 2012; Feenstra and Erkel, 2007). Despite activated alumina method being popular, it has some limitations such as it is not effective when the total dissolved solids in water exceeds $1500 \mathrm{mg} / \mathrm{L}$. It is also $\mathrm{pH}$ selective hence it works better under certain $\mathrm{pH}$ levels and when it is left out of operation for 2 or 3 days it provides room for microorganism growth (Shrivastava and Vani, 2009).

There is no single method of treating drinking water which meets all the standards. Therefore, there is a need for obtaining knowledge on the removal of fluoride using resourceful techniques under ideal conditions using different naturally occurring materials. The current research aims at improving the fluoride removal process in drinking water using the naturally occurring rock materials using bauxite, gypsum and magnesite obtained in Tanzania. The scope of the work was the calcination of bauxite, gypsum and magnesite at temperature of
350 to $600^{\circ} \mathrm{C}$ to improve their adsorbent capability.

\section{MATERIALS AND METHODS}

Boulders of magnesite, gypsum and bauxite sourced from Chambogo, Makanya and Lushoto, respectively, were crushed and milled separately and then sieved through standard sieves of $\geq 0.075$ $\mathrm{mm}$. The materials were then calcinated in a furnace at different temperatures of $350^{\circ} \mathrm{C}, 400^{\circ} \mathrm{C}, 450^{\circ} \mathrm{C}, 500^{\circ} \mathrm{C}, 550^{\circ \circ} \mathrm{C}$ and $600^{\circ} \mathrm{C}$ for duration of 2 hours. The samples were then removed from the furnace and left to cool to room temperature.

Different dosages of 1 to 10 grams of bauxite, gypsum and magnesite were weighed separately using a weighing balance, and then placed in the beaker containing $100 \mathrm{~mL}$ of $16.7 \mathrm{mg} / \mathrm{L}$ fluoride contaminated water obtained from Maji ya Chai river in Arusha. Samples were collected at location with coordinates $3.37111 \mathrm{~S}$ and $36.8964 \mathrm{E}$, using the polyethylene sampling bottles, then was transported to the laboratory and stored at room temperature of $25^{\circ} \mathrm{C}$ as further analysis was on going.

Using the magnetic stirrer at $100 \mathrm{rpm}$, the material and fluoride contaminated natural water was allowed to stay in contact while stirring at different time intervals for the first 2, 4, 6,8 and 10 minutes and then for 20, 30, 40, 50 and 60 minutes. At the end of each contact time, the water sample was filtered, then $\mathrm{pH}$, fluoride concentration and ionic impurities concentration, iron and sulphate parameters were analysed. This was performed at each calcinated temperature. The calcination temperatures at which fluoride removal was the highest for each adsorbent were then mixed together at the ratios of $1: 2: 3,3: 2: 1$ and 2:3:1 as mass ratios, bauxite: gypsum: magnesite, respectively. The fluoride removal efficiency by each adsorbent 
bauxite, magnesite and gypsum, respectively was calculated using the equation.

$$
R=\frac{C l-C f}{C i} \times 100 \%
$$

Where $\mathrm{R}$ is removal efficiency, $\mathrm{Cf}$ and $\mathrm{Ci}$ are the final and initial fluoride concentration in solution (mg/L) respectively. The removal capacity was determined using the equation (2).

$$
q e=\frac{(C o-C f) V}{m}
$$

Where $\mathrm{q}_{\mathrm{e}}$ is the amount of adsorbed fluoride at equilibrium (mg/g), Co and $\mathrm{Cf}$ represents the initial and final fluoride concentration $(\mathrm{mg} / \mathrm{L}), \mathrm{V}$ is the volume of solution (L) and $m$ the mass of adsorbent in grams $(\mathrm{g})$.

The adsorption isotherm was studied by fitting the data with Langmuir and Freundlich isotherms as expressed in equations (3) and (4). In Langmuir isotherm adsorption is assumed to occur at specific homogeneous sites where there is no additional adsorption to take place (Piccin et al., 2011).

$$
\frac{1}{q_{q}}=\left[\frac{1}{Q_{m} K_{l}}\right] \frac{1}{c_{q}}+\frac{1}{Q_{m}}
$$

Where, qe is adsorption capacity $\left(\mathrm{mg} \mathrm{g}^{-1}\right)$, $\mathrm{Ce}$ is Equilibrium concentration $\left(\mathrm{mg} \mathrm{L}^{-1}\right)$, $\mathrm{Q}_{\mathrm{m}}$ is maximum monolayer adsorption $\left(\mathrm{mol} \mathrm{g}^{-1}\right)$ and $\mathrm{Kl}$ is Langmuir constant $(\mathrm{L}$ $\left.\mathrm{mol}^{-1}\right)$.

The Freundlich isotherm assumes a multilayer adsorption, mostly used to define adsorption characteristics for heterogeneous surfaces (Kebede et al., 2016).

$$
Q=F C^{1 / n}
$$

Where $\mathrm{Q}$ is adsorption Capacity $\left(\mathrm{mg} \mathrm{g}^{-1}\right)$, $\mathrm{F}$ is Freundlich constant $\left(\mathrm{Lkg}^{-1}\right), \mathrm{C}$ is Equilibrium concentration $\left(\mathrm{mg} \mathrm{L}^{-1}\right)$ and $1 / \mathrm{n}$ is heterogeneity factor (dimensionless).

\section{RESULTS AND DISCUSSION}

The raw materials, which are bauxite, magnesite and gypsum, were collected from Usambara Mountains in Lushoto district, Chambogo in Same district and Makanya in Same district, respectively. The materials contained some sulphite and metal oxide as impurities (Table 1). Bauxite contained about $57.4 \%$ of $\mathrm{Al}_{2} \mathrm{O}_{3}$, gypsum contained $29.4 \%$ of $\mathrm{CaO}$ and magnesite contained about $47.0 \%$ of $\mathrm{MgO}$. These are the major compounds in the raw materials used production of absorbents.

Table 1: Analysis of the material elements (XRF) results in percentage

\begin{tabular}{|l|c|c|c|c|}
\hline Material Constituent & $\mathrm{Al}_{2} \mathrm{O}_{3}$ & $\mathrm{SiO}_{2}$ & $\mathrm{CaO}$ & $\mathrm{MgO}$ \\
\hline Bauxite & 57.41 & 4.18 & $<0.01$ & $<0.01$ \\
\hline Gypsum & 2.07 & 8.98 & 29.36 & 1.27 \\
\hline Magnesite & 0.12 & 2.30 & 0.22 & 47.03 \\
\hline
\end{tabular}

\section{Material Calcination}

When bauxite (Aluminium hydroxide), gypsum (calcium sulphate dihydrate) and magnesite (magnesium carbonate) were calcinated, the following reactions took place as observed in the equations (5), (6) and (7).

$$
\begin{aligned}
& 2 \mathrm{Al}(\mathrm{OH})_{3(\mathrm{~s})} \longrightarrow \mathrm{Al}_{2} \mathrm{O}_{3(\mathrm{~s})}+3 \mathrm{H}_{2} \mathrm{O}_{(\mathrm{g})} \\
& \mathrm{CaSO}_{4} \cdot 2 \mathrm{H}_{2} \mathrm{O}_{(\mathrm{s})} \longrightarrow \mathrm{CaO}_{(\mathrm{s})}+\mathrm{SO}_{3(\mathrm{~s})}+2 \mathrm{H}_{2} \mathrm{O}_{(\mathrm{g})} \\
& \mathrm{MgCO}_{3(\mathrm{~s})} \longrightarrow \mathrm{MgO}_{(\mathrm{s})}+\mathrm{CO}_{2(\mathrm{~g})} \quad \ldots \ldots \ldots \ldots \ldots \ldots
\end{aligned}
$$




\section{Laboratory Analysis}

The water quality parameters analysed from the raw water were found to be within WHO and TBS standards except for fluoride which was found to be much higher compared to the standards (Table 2). Different conditions and factors affecting the fluoride removal were

Table 2: Analysis results of raw water observed and the studied factors such as particle size, contact time, dosage of the adsorbent, and calcination temperature were observed. Likewise, the removal capacity of each adsorbent was determined, the best temperature for media calcination and the best composite ratio was also determined through the analysis.

\begin{tabular}{|l|c|c|c|}
\hline Parameter & Amount in raw water & WHO Standards & TBS Standards \\
\hline Fluoride $(\mathrm{mg} / \mathrm{L})$ & 16.7 & 1.5 & $1.5-4.0$ \\
\hline Chloride $(\mathrm{mg} / \mathrm{L})$ & 29.9 & 250 & $200-800$ \\
\hline Nitrate $(\mathrm{mg} / \mathrm{L})$ & 7.6 & 50 & $10-75$ \\
\hline $\mathrm{pH}$ & 8.14 & $6.5-8.5$ & $6.5-9.2$ \\
\hline Sulphate $(\mathrm{mg} / \mathrm{L})$ & BDL & 500 & $200-600$ \\
\hline
\end{tabular}

\section{Effect of Dosage}

Analysis was conducted to establish removal efficiency within 10 minutes using different concentration dosages. Different doses of $1 \mathrm{~g}$ to $10 \mathrm{~g}$ of adsorbent in $200 \mathrm{ml}$ contaminated water with initial fluoride concentration of $16.7 \mathrm{mg} / \mathrm{L}$ were used. Removal efficiency under different dosage conditions was as shown in Figure 1. Similar trend of removal efficiency was observed by (Patnaik et al., 2016). The removal efficiency was observed to increase from $36.5 \%$ to $87.7 \%$ with increased adsorbent dosage from 1 to $10 \mathrm{~g}$. The increase in fluoride removal efficiency with increase in the adsorbent dose was due to the increase in surface area; hence more active sites were available for adsorption of fluoride. However after a definite adsorbent dose, the percentage of removal did not increase significantly and that dose was considered as best dose which was $10 \mathrm{~g}$.

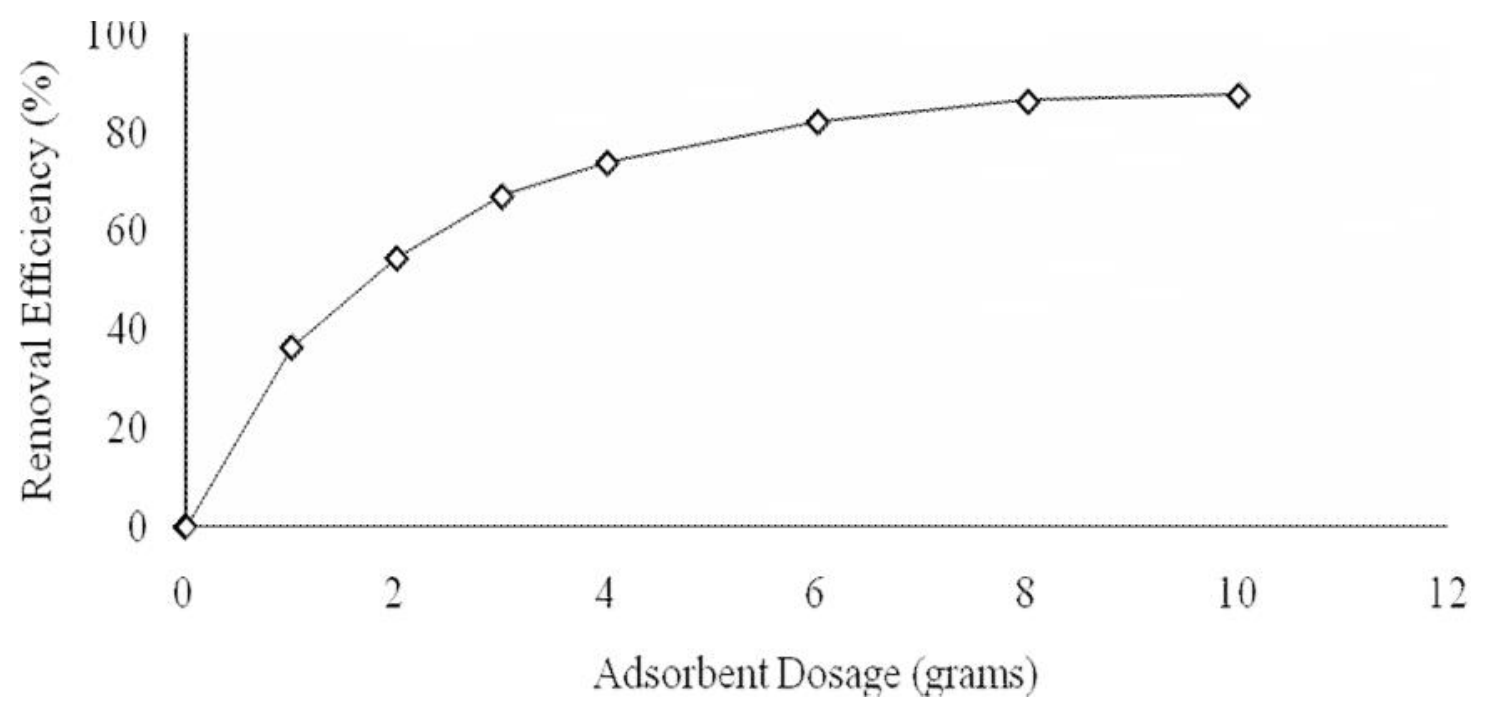

Figure 1: Adsorbent dosage in relation with fluoride removal efficiency 


\section{Effect of Adsorbent Dosage on Fluoride Removal Capacity}

Figure 2 shows that the removal capacity kept decreasing as the dosage increased at all the contact time. The same trend of result was observed by Patnaik et al. (2016). The adsorption process was observed to take place in the first 2 minutes contact time of the reaction. At 10 minutes contact time where the highest removal capacity was observed, the equilibrium removal capacity decreased from $1.13 \mathrm{mg} / \mathrm{g}$ to $0.27 \mathrm{mg} / \mathrm{g}$, this was also observed at the contact time of 2, 4, 6, and
8 minutes where removal capacity decreased from $0.9 \mathrm{mg} / \mathrm{g}$ to $0.26 \mathrm{mg} / \mathrm{g}$, $0.98 \mathrm{mg} / \mathrm{g}$ to $0.27 \mathrm{mg} / \mathrm{g}, 1.06 \mathrm{mg} / \mathrm{g}$ to 0.27 $\mathrm{mg} / \mathrm{g}$ and $1.08 \mathrm{mg} / \mathrm{g}$ to $0.27 \mathrm{mg} / \mathrm{g}$ respectively. The removal capacity was observed to decrease to $0.27 \mathrm{mg} / \mathrm{g}$ of fluoride as the dosage increased. That is more fluoride ions were adsorbed as the adsorbent dose increases, hence adsorption capacity reached was $0.27 \mathrm{mg} / \mathrm{g}$ of fluoride. After reaching $0.27 \mathrm{mg} / \mathrm{g}$, fluoride removal seized. Desorption will begin depending on initial concentration and media volume/weight used.

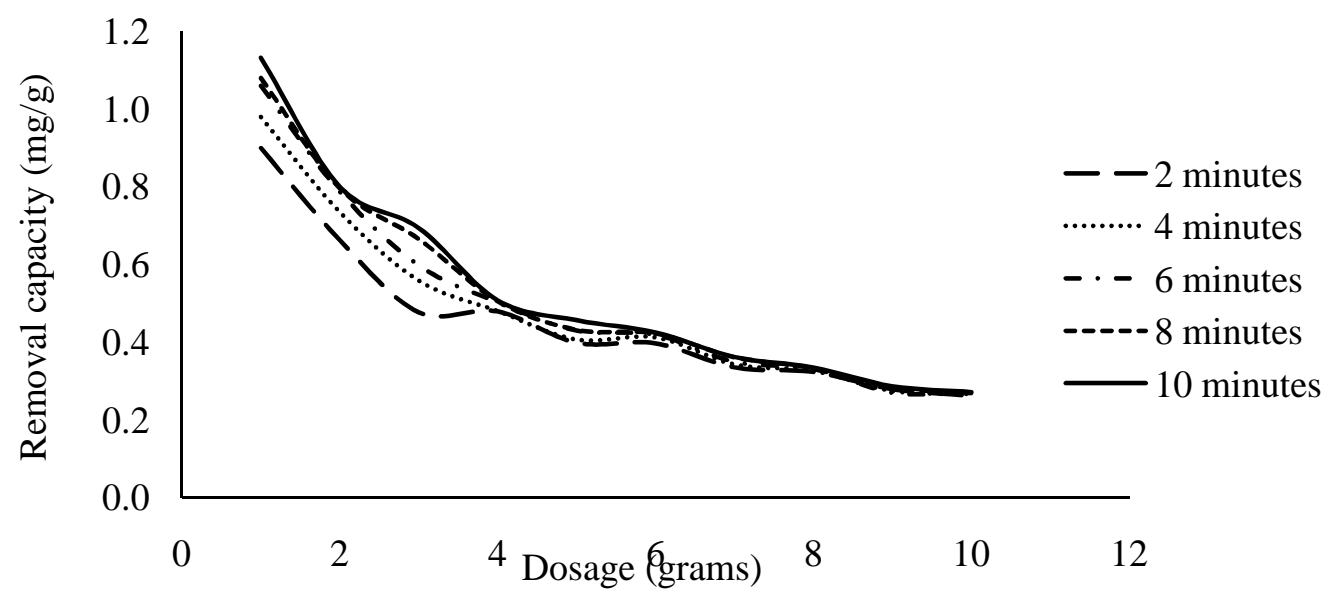

Figure 2: Effect of adsorbent dosage on the fluoride removal capacity at different contact times

Figure 3 shows bauxite had highest removal capacity in all calcination temperatures. Gypsum removal capacity was high at lower calcination temperature of $350^{\circ} \mathrm{C}$ and poor at higher calcination temperature of $600^{\circ} \mathrm{C}$. Magnesite had highest capacity at higher temperatures of $600^{\circ} \mathrm{C}$. This was also reported by Singano (2000), that with magnesite fluoride removal was high at higher calcination temperatures. When magnesite is calcinated the decomposition of carbonates takes place and forms magnesium oxide $\mathrm{MgO}$, which is the one responsible for fluoride removal. The decomposition of the carbonates occur starting at temperature of $400^{\circ} \mathrm{C}$ and hence proceeds rapidly above temperature of $500^{\circ} \mathrm{C}$ (Singano, 2000). Magnesite reaction on fluoride removal can be seen in equation (8).

$$
\mathrm{MgO}_{(\mathrm{s})}+\mathrm{H}_{2} \mathrm{O}_{(\mathrm{l})}+\mathrm{F}_{(\mathrm{aq})}^{-} \longrightarrow \mathrm{Mg}(\mathrm{OH}) \mathrm{F}_{(\mathrm{aq})}+\mathrm{OH}_{(\mathrm{aq})}^{-}
$$




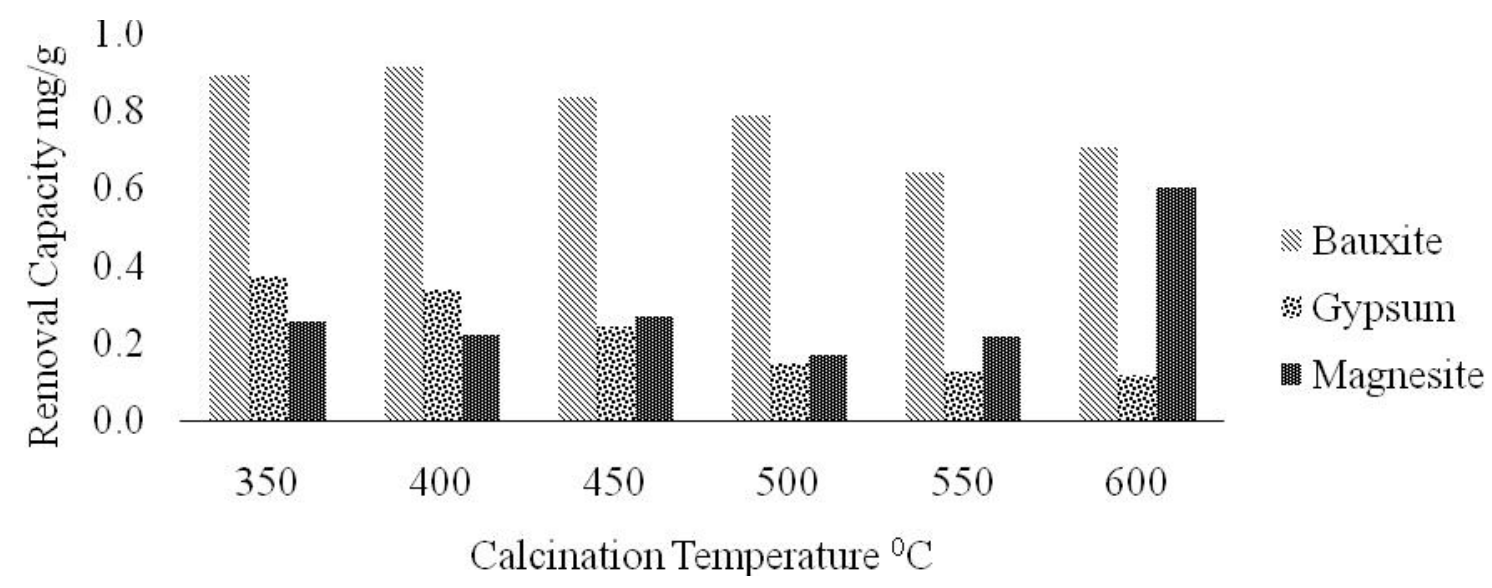

Figure 3: Removal capacity of each adsorbent at different calcination temperatures

Despite the high removal capacity, bauxite increased the water turbidity and colour in the treated water. Also, bauxite and gypsum lowered the $\mathrm{pH}$ value to 8.04 and 8.06, respectively, while magnesite raised $\mathrm{pH}$ to 8.62 as also reported by Thole et al. (2013). The rise of $\mathrm{pH}$ by magnesite was also reported by Singano (2000). Bauxite and gypsum lowering $\mathrm{pH}$ can be explained by the presence of sulphite in bauxite and gypsum.

The fluoride removal in drinking water using bauxite is through ion exchange processes where fluoride ion with $\mathrm{OH}^{-}$ groups they exchange. Aluminium oxide $\left(\mathrm{Al}_{2} \mathrm{O}_{3}\right)$ being in larger content in bauxite as well as sulphite $\mathrm{SO}_{3}{ }^{-}$, these are covalent oxides, hence when dissolve in water they bind the water molecules and releases protons which results to the lowering of pH (Cherukumilli et al., 2017; Thole et al., 2013).

Magnesite is mainly $\mathrm{MgCO}_{3}$ compound, when magnesite is calcinated the decomposition of carbonates takes place and forms magnesium oxide $\mathrm{MgO}$ which is the one responsible for fluoride removal and the cause of $\mathrm{pH}$ rise. The decomposition of the carbonates occur starting at temperature of $400^{\circ} \mathrm{C}$ and hence proceeds rapidly above temperature of $500^{\circ} \mathrm{C}$ (Singano, 2000).
Moreover, gypsum calcinated at low temperature of $150^{\circ} \mathrm{C}$ to $300^{\circ} \mathrm{C}$ gave better performance in fluoride removal though with the highest residual number of other ions such as sulphate and iron, which are not within the recommended standards. However, gypsum calcinated at temperatures above $300^{\circ} \mathrm{C}$ introduces less ionic contaminants in treated water (Thole et al., 2011). Results in Table 3 prove the presence of residual sulphate in gypsum calcinated at temperature of $350^{\circ} \mathrm{C}$, but the amount is found to be within the recommended standards and iron level was found to be below the detection limit.

Surface area was determined using BET (Brunauer-Emmett-Teller) method and pore diameter was determined using (Barrett-Joyner-Halenda) BJH method. Magnesite prepared at $600^{\circ} \mathrm{C}$ had a smaller surface area of $83.1 \mathrm{~m}^{2} / \mathrm{g}$ compared to bauxite with $103 \mathrm{~m}^{2} / \mathrm{g}$ and gypsum 115.5 $\mathrm{m}^{2} / \mathrm{g}$. Bauxite prepared at $400^{\circ} \mathrm{C}$ had the largest pore diameter of $32.4 \AA$ compared to magnesite $31.8 \AA$ and gypsum with 32.3 $\AA$. The highest removal efficiency for bauxite, gypsum and magnesite were observed at temperatures of $400^{\circ} \mathrm{C}, 350^{\circ} \mathrm{C}$ and $600^{\circ} \mathrm{C}$, respectively. Similarly, Singano (2000), reported best fluoride removal capacity of magnesite to be at $600^{\circ} \mathrm{C}$. For the case of gypsum, performance was observed to be best at lower temperature as reported by Thole $e t$ 
al. (2011), hence $350^{\circ} \mathrm{C}$ calcination temperature for gypsum was best in this study.

The composite used comprised adsorbents with best performance calcination temperatures that is bauxite calcinated at $400^{\circ} \mathrm{C}$, gypsum at $350^{\circ} \mathrm{C}$ and magnesite calcinated at $600^{\circ} \mathrm{C}$. The ratios used were 1:2:3, 2:3:1 and 3:2:1 bauxite: gypsum: magnesite, respectively. The results are shown in Table 4.

Table 3: Treated water analysis results

\begin{tabular}{|c|c|c|c|c|c|}
\hline Material & $\begin{array}{c}\text { Initial Fluoride } \\
(\mathrm{mg} / \mathrm{L})\end{array}$ & Final $\mathrm{pH}$ & $\begin{array}{c}\text { Fluoride } \\
(\mathrm{mg} / \mathrm{L})\end{array}$ & $\begin{array}{c}\text { Iron } \\
(\mathrm{mg} / \mathrm{L})\end{array}$ & $\begin{array}{c}\text { Sulphate } \\
(\mathrm{mg} / \mathrm{L})\end{array}$ \\
\hline Bauxite & 16.7 & 8.04 & 8.5 & 1.55 & 24 \\
\hline Gypsum & 16.7 & 8.06 & 14.4 & BDL & 190 \\
\hline Magnesite & 16.7 & 8.62 & 14.7 & 0.75 & 18 \\
\hline WHO (2006) Standards & & $6.5-8.5$ & 1.5 & 0.3 & 500 \\
\hline TBS (2009) Standards & & $6.5-9.2$ & $1.5-4.0$ & $0.3-1.0$ & $200-600$ \\
\hline
\end{tabular}

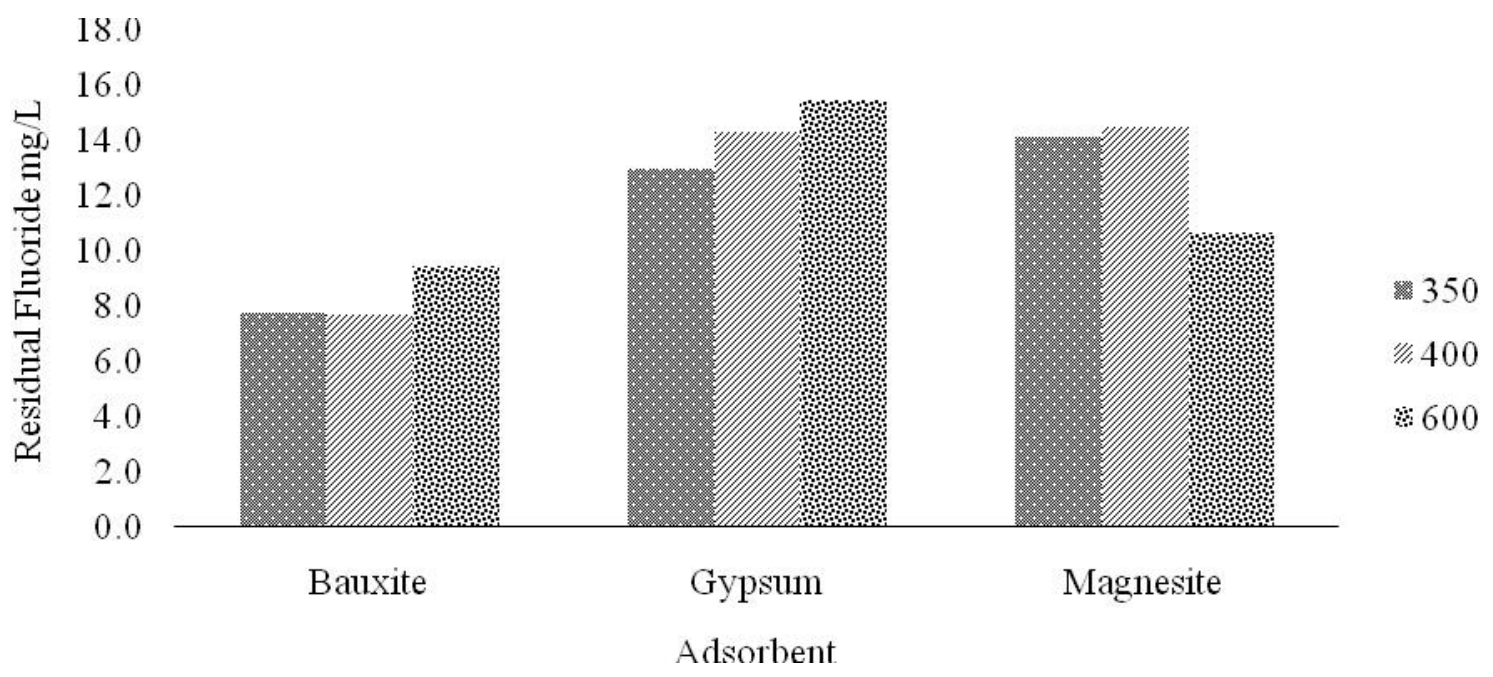

Figure 4: Effect of adsorbent calcination temperature on fluoride removal

Table 4: Treated water test results of the composite ratios

\begin{tabular}{|l|c|c|c|c|c|}
\hline Parameter & $\begin{array}{c}\text { Composite } \\
\text { Ratio 1:2:3 }\end{array}$ & $\begin{array}{c}\text { Composite } \\
\text { Ratio 2:3:1 }\end{array}$ & $\begin{array}{c}\text { Composite } \\
\text { Ratio 3:2:1 }\end{array}$ & $\begin{array}{c}\text { WHO } \\
\text { Standards }\end{array}$ & $\begin{array}{c}\text { National } \\
\text { Standard (TBS) }\end{array}$ \\
\hline $\begin{array}{l}\text { Removal Efficiency } \\
(\%)\end{array}$ & 90.9 & 87.6 & 84.4 & & \\
\hline Fluoride (mg/L) & 1.52 & 2.07 & 2.6 & 1.5 & $1.5-4.0$ \\
\hline Sulphate $(\mathrm{mg} / \mathrm{L})$ & 175 & 165 & 168 & 500 & $200-600$ \\
\hline Iron $(\mathrm{mg} / \mathrm{L})$ & BDL & BDL & BDL & 0.3 & $0.3-1.0$ \\
\hline
\end{tabular}

All values were within the WHO and TBS allowable drinking water quality standards.
Figure 5 illustrates the residual fluoride with the respective ratios. 


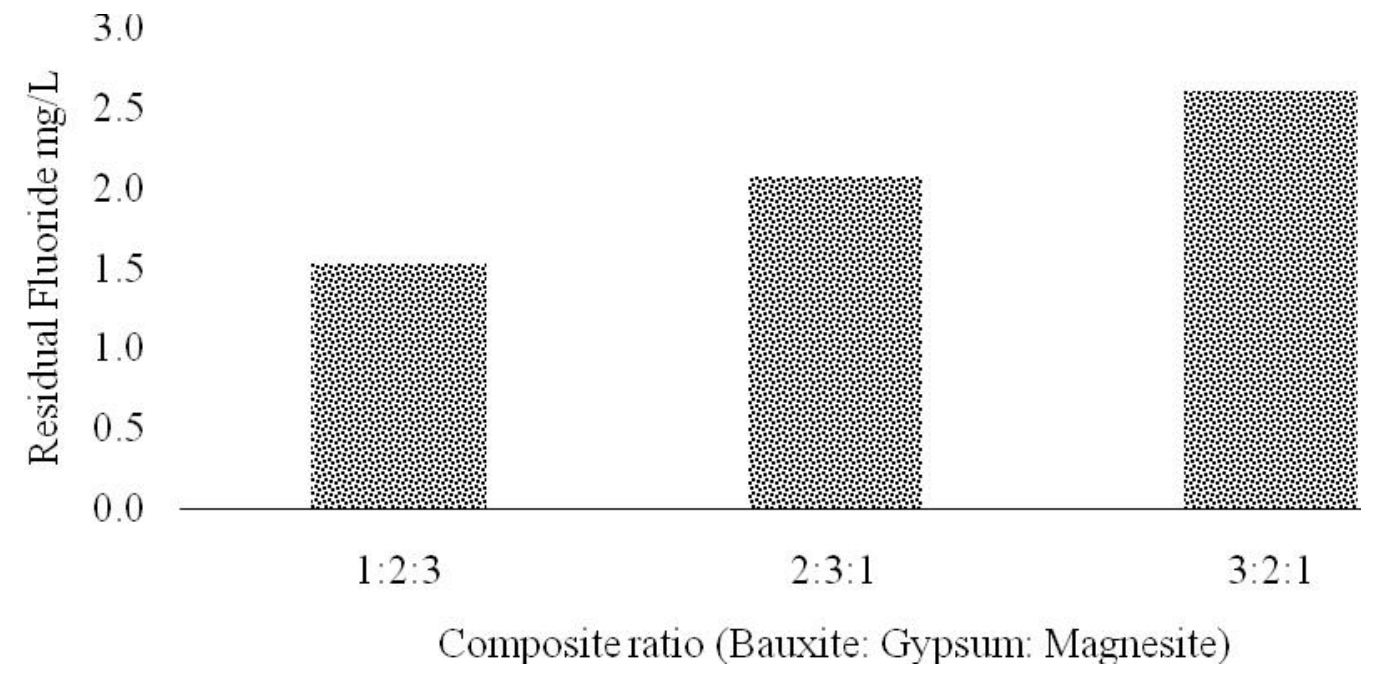

Figure 5: The effect of composite ratio on residual fluoride

\section{Adsorption Isotherms}

Composite ratio 1:2:3 bauxite, gypsum and magnesite, respectively, as shown in Figures 6 and 7 demonstrate sorption isotherms obtained from the experimental data fitted. Most of the data set adhered more strongly to Langmuir sorption model which gave the value of $r=0.00575$ which lies in the range $0<\mathrm{r}<1$ which indicates a favourable adsorption. For Freundlich model, the value of $1 / \mathrm{n}$ was 0.0521 in which the value of $\mathrm{n}$ was greater than 10 hence out of range.

The results obtained from fitting the experimental data into the Langmuir and Freundlich equations have been summarized in Table 5, whereas when $r$ value lies in the range $0<\mathrm{r}<$ indicates a favourable adsorption and $\mathrm{n}$ value indicates good adsorption characteristics when is in range 2 to 10 .

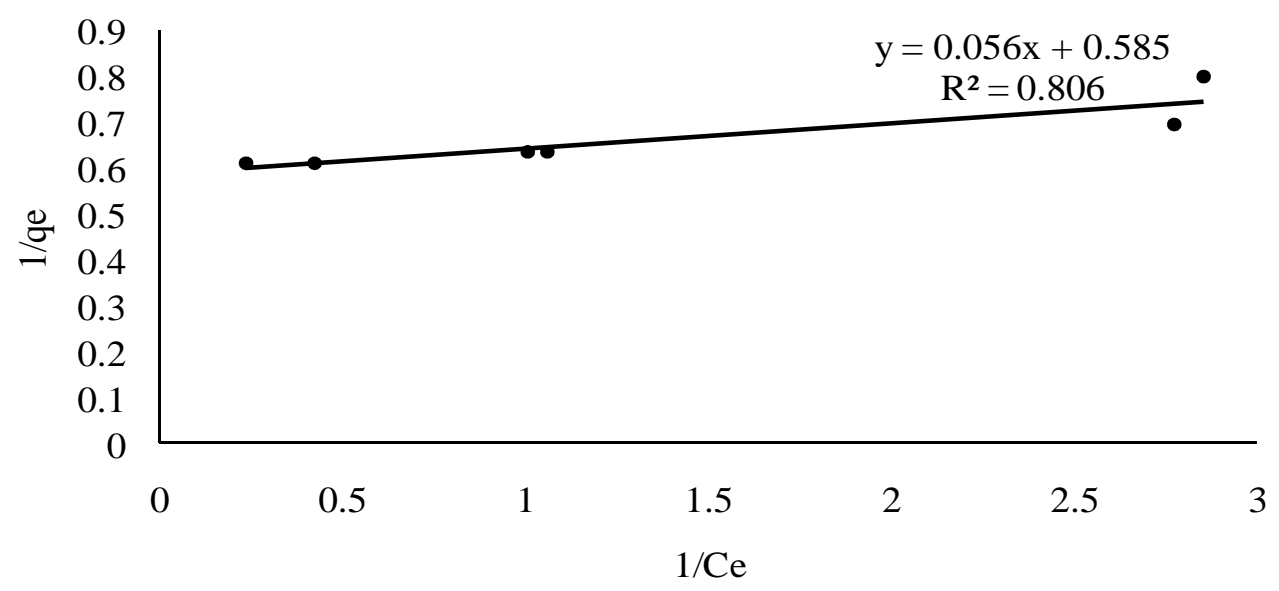

Figure 6: Langmuir isotherm for composite ratio 1:2:3 


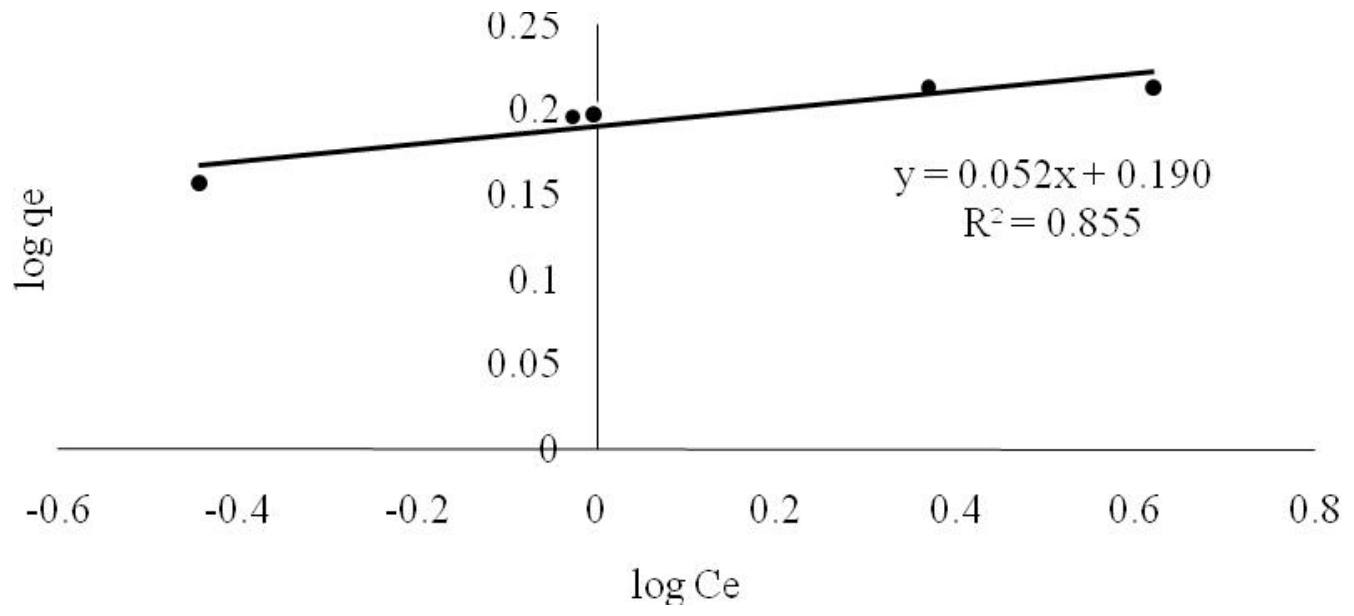

Figure 7: Freundlich isotherm for composite ratio 1:2:3

Table 5: Fitted parameters for Langmuir and Freundlich isotherms of the composites

\begin{tabular}{|l|c|c|c|c|c|c|}
\hline & \multicolumn{4}{|c|}{ Langmuir Isotherm } & \multicolumn{2}{c|}{ Freundlich Isotherm } \\
\hline & $\mathrm{R}^{2}$ & $\mathrm{R}$ & $1 / \mathrm{K}_{\mathrm{L}} \mathrm{Qm}$ & $1 / \mathrm{Qm}$ & $1 / \mathrm{n}$ & $\mathrm{R}^{2}$ \\
\hline $1: 2: 3$ & 0.8065 & 0.0058 & 0.0566 & 0.5859 & 0.0521 & 0.8554 \\
\hline $2: 3: 1$ & 0.9697 & 0.1895 & 0.1528 & 0.5965 & 0.1308 & 0.9913 \\
\hline $3: 2: 1$ & 0.9525 & 0.1022 & 0.3096 & 0.5886 & 0.1772 & 0.9724 \\
\hline
\end{tabular}

\section{CONCLUSIONS}

Drinking water defluoridation with the composite materials of bauxite, gypsum and magnesite is possible and provides the best results, where the dosage of the adsorbent is inversely proportional to the removal capacity with constant initial fluoride concentration. The adsorption process was observed in the first 2 minutes contact time of the reaction.

Bauxite gave the highest fluoride removal efficiency compared to gypsum and magnesite at all calcination temperatures tested, though it altered the water quality parameters such as $\mathrm{pH}$, hence with the composite of the three adsorbents the water quality parameters were balanced.

Calcination temperatures of $350^{\circ} \mathrm{C}$ for gypsum, $400^{\circ} \mathrm{C}$ for bauxite and $600^{\circ} \mathrm{C}$ for magnesite were found to be the best in the removal of fluoride. The findings illustrate that the adsorbent material composite of the best calcination temperatures gave the highest removal efficiency at all the ratios tested; also, all gave the lowest sulphate and iron levels as impurities.

The best composite ratio 1:2:3 bauxite, gypsum and magnesite respectively had the highest removal efficiency with low sulphate and iron levels which were found to be within the recommended WHO standards. Whereas adsorption isotherms of Langmuir model had the best fit, the adsorption characteristics were good and the adsorption was favourable. Hence best for the removal of excess fluoride in drinking water.

Therefore, using the naturally occurring materials for the case of bauxite, gypsum, magnesite and its composite of best calcination temperature of each adsorbent, can be used as a treatment technology of drinking water in highly contaminated fluoride regions when upscaled to large municipal treatment plants. 


\section{AKNOWLEDGEMENT}

Our sincere gratitude and thanks to the Almighty God for his guidance, protection, strength and help throughout the research work. The authors are grateful to DAFWAT project for the support in the laboratory research activities that has led to this output. Thank you and may God Almighty bless you.

\section{REFERENCES}

Al-Hawamdeh A.E.I.D.A.S. and AlHawamdeh S. (2013). Defluoridation Of Water By Natural Materials: Is It Adsorption? Proceedings of the $13^{\text {th }}$ International Conference of Environmental Science and Technology September, 5-7.

Ayris P.M. and Delmelle P. (2012). The immediate environmental effects of tephra emission. 1905-1936. https://doi.org/10.1007/s00445-0120654-5

Borgnino L., Garcia M.G., Bia G., Stupar Y.V., Le P. and Depetris P.J. (2013). Mechanism of fluoride release in sediments of Argentina's central region. Science of the Total Environment, 443: 245-255.

DOI: $\underline{10.1016 / j . s c i t o t e n v .2012 .10 .093}$

Cherukumilli K., Delaire C., Amrose S. and Gadgil A.J. (2017). Factors Governing the Performance of Bauxite for Fluoride Remediation of Groundwater. Environmental Acience and Technology, American Chemical Society, 51(4): 2321-2328. https://doi.org/10.1021/acs.est.6b04601

Fawell J., Bailey K., Chilton J., Dahi E., Fewtrell L. and Magara Y. (2006). Fluoride in drinking-water. World Health Organization, Geneva, Switzerland.

https://apps.who.int/iris/handle/10665/4 3514

Feenstra L. and Erkel J. Van. (2007). Arsenic in groundwater: Overview and evaluation of removal methods.
International Groundwater Resources Assessment Centre, Report No. SP 2007-2, Utrecht, December, 1-23.

Kebede B., Beyene A., Fufa F., Megersa M. and Behm M. (2016). Experimental evaluation of sorptive removal of fluoride from drinking water using iron ore. Applied Water Science, 6(1): 5765. https://doi.org/10.1007/s13201-0140210-x

Lavecchia R., Medici F., Piga L., Rinaldi G. and Zuorro A. (2012). Fluoride removal from water by adsorption on a high alumina content bauxite. 26: 225230.

https://doi.org/10.3303/CET1226038

Owusu-Agyeman I., Shen J. and Schäfer, A.I. (2018). Renewable energy powered membrane technology: Impact of $\mathrm{pH}$ and ionic strength on fluoride and natural organic matter removal. Science of the Total Environment, 621: 138147.

https://doi.org/10.1016/j.scitotenv.2017. 11.111

Ozsvath D. (2015). Fluoride and environmental health: A Review. Reviews in Environmental Science and Bio/Technology 8(1):59-79. https://doi.org/10.1007/s11157-0089136-9

Patnaik S., Pc M., Rn N. and Ak G. (2016). Analytical and Bioanalytical Techniques Removal of Fluoride from Aqueous Solution Using Chitosan-Iron Complex. $7(4)$ : https://doi.org/10.4172/21559872.1000326

Piccin J.S., Dotto G.L. and Pinto L.A.A. (2011). Adsorption Isotherms And Thermochemical Data of Fd and C Red $\mathrm{N}^{\circ} 40$ Binding By Chitosan. Brazillian Journal of Chemical Engineering, 28(2): 295-304. DOI: $10.1590 / \mathrm{S} 0104-$ 66322011000200014

Rao N. (2003). Fluoride and environment A review. in Martin J. Bunch, V. Madha Suresh and T. Vasantha Kumaran, eds., Proceedings of the Third International Conference on 
Environment and Health, Chennai, India, 15-17 December, 2003. Chennai: Department of Geography, University of Madras and Faculty of Environmental Studies, York University. $386-399$.

Shen J., Richards B.S. and Schäfer A.I. (2016). Renewable energy powered membrane technology: Case study of St. Dorcas borehole in Tanzania demonstrating fluoride removal via nanofiltration / reverse osmosis. Separation and Purification Technology, 170: 445-452. https://doi.org/10.1016/j.seppur.2016.06 .042

Shrivastava B.K. and Vani A. (2009). Comparative Study of Defluoridation Technologies in India. Asian Jiurnal of Experimental Science, 23(1): 269-274.

Singano J.J. (2000). Investigation of the mechanisms of Defluoridation of drinking water by using locally available magnesite. MSc Dissertation, University of Dar es Salaam, Tanzania.

Sivasankar V., Darchen A., Omine K. and Sakthivel R. (2016). Fluoride: A World Ubiquitous Compound, Its Chemistry, and Ways of Contamination. 5-33. https://doi.org/10.1007/978-3-31940686-2

Thole B., Masamba W.R.L. and Mtalo F. (2013). Water defluoridation by bauxite-gypsum-magnesite (B-G-Mc) based filters calcined at $350-500^{\circ} \mathrm{C}$. International Journal of Physical Sciences, $\quad$ 8(19): 956-962. https://doi.org/10.5897/IJPS10.668

Thole B., Mtalo F.W. and Masamba W.R.L. (2011). Water defluoridation with $150-300^{\circ} \mathrm{C}$ calcined BauxiteGypsum-Magnesite (B-G-Mc) filters. WIT Transactions on Ecology and the Environment, 145: 383-393. https://doi.org/10.2495/WRM110331

Thole B. and Mtalo F.W. (2012). Groundwater Defluoridation with Raw Bauxite, Gypsum, Magnesite and Their Composites. 1222-1228. https://doi.org/10.1002/clen.201100111

Tomar V. and Kumar D. (2013). A critical study on efficiency of different materials for fluoride removal from aqueous media, Chemistry Central Journal, $7(51)$. https://doi.org/10.1186/1752-153X-751

Wambu E.W., Agong S.G., Anyango B., Akuno W. and Akenga T. (2014). High fluoride water in Bondo-Rarieda area of Siaya County, Kenya: A hydrogeological implication on public health in the Lake Victoria Basin. 1-8. https://doi.org/10.1186/1471-2458-14462 